\title{
JOHN MACCULLOCH, M.D., F.R.S. (1773-1835) (THE PRECURSOR OF THE DISCIPLINE OF MALARIOLOGY)
}

\author{
by
}

\section{J. BRUCE-CHWATT*}

FOR CENTURIES "marsh fever" or "ague" was common in some areas of England, particularly in the Thames estuary, south-east Kent, the Fen country of Cambridgeshire, parts of Somerset and Lancashire. ${ }^{1}$ Originally the word "ague" meant any acute fever but gradually it became restricted to the symptoms of plasmodial infection, as we know it. ${ }^{2}$ The Italian common term "mal'aria" was introduced into this country in 1740 by Horace Walpole, ${ }^{3}$ in his letters from Italy. Other writers (Michael Kelly, John Forsyth, Shelley and Byron) followed Walpole's example but it seems that in an English scientific publication the term "malaria" was used for the first time in 1827.4 The author of this book, John Macculloch, M.D., F.R.S., is better known as one of the prominent British geologists. It is as a geologist that he is described in the Dictionary of national biography by the Reverend Professor T. G. Bonney; ${ }^{5}$ this and a few other biographical notes ${ }^{6}$ as well as a more recent review ${ }^{7}$ reveal Macculloch's unusual talents, breadth of interests and striking personality.

John's father James, one of the Macculloch's of Nether Ardwell in Galloway ${ }^{8}$

*L. J. Bruce-Chwatt, M.D., F.R.C.P., Emeritus Professor of Tropical Hygiene, University of London., Wellcome Museum of Medical Science, 183 Euston Road, London NW1 2BP.

${ }^{1}$ G. H. F. Nuttall, L. Cobbett and T. Strangeways-Pigg, 'Studies in relation to malaria, $I^{\prime}, J^{\cdot}$ Hyg., 1901, 1: 26-44. W. P. MacArthur, 'A brief history of English malaria', Br. med. Bull., 1951, 8: 76-79.

Ibid. S. Jarcho, 'A cartographic and literary study of the word malaria', J. Hist. Med., 1970, 25: 31-39, p. 35. See also, L. J. Bruce-Chwatt, 'Ague as malaria', J. trop. Med. Hyg., 1976, 79: 168-176.

' ". . . There is a horrid thing called the mal'aria, that comes to Rome every summer and kills one. ..." J. A. H. Murray (editor), New English dictionary on historical principles, Oxford, Clarendon Press, 1908, vol. 6, p. 78.

- In the eleventh edition of the Encyclopedia Britannica, considered as a standard for all subsequent editions, the following entry will be found: "Malaria, an Italian colloquial word (from mal ariabad air) introduced into English medical literature by Macculloch in 1827, as a substitute for the more restricted terms marsh miasm or paludal poison." ('Macculloch, John', and 'Malaria', Encyclopedia Britannica, 11 th ed., Cambridge University Press, 1911, vol. 17, pp. 208, 461). See also, H. Scott, A history of tropical medicine, 2 vols., London, Arnold, 1939, vol. 1, p. 116; P. F. Russell, Man's mastery of malaria, London, Oxford University Press, 1955, p. 19.

' T. G. Bonney, 'John Macculloch, 1773-1835', Dictionary of national biography, 1909, vol. 12, pp. 461-463 (re-issue of vol. 35 of 1893, pp. 17-19).

- 'Cornwall, Aug. 20th. Macculloch John' [obituary], Gentleman's mag., 1835, 2: 556. 'John M'Culloch, Esq. MD' [obituary], Annual Biography and Obituary, 1836, 20: 24-34. Ch. Lyell, in 'Address to the Geological Society, delivered on the 19th of February 1836', Proc. geol. Soc. Lond., 1836, 2: 358-359. Encyclopedia Britannica, op. cit., note 4 above.

'V. A. Eyles, 'John Macculloch, F.R.S. and his geological map; an account of the first geological survey of Scotland', Ann. Sci., 1937, 2: 114-129.

- The name Cul Loch means "dwellers in the loch", the ancestral family having settled on an island in Myreton Loch. The estate remained in the family until Sir Godfrey MacCulloch was beheaded 
had a business in France, but lost most of his fortune during the French Revolution and was obliged to return to Britain. John's mother was the daughter of Thomas de Lisle, a jurat of Guernsey. John, the third child, was born in Guernsey in 1773. A precocious and lonely child, he went first to a school at Plympton and afterwards to the grammar school at Lostwithiel in Cornwall. The master of this school, Mr. MacGillivray, soon recognized his pupil's talents and treated him with much kindness. John entered the University of Edinburgh where he graduated M.D. in 1793, having submitted a thesis on electricity. ${ }^{\circ}$ After graduation he travelled in Scotland and formed a close friendship with Sir Walter Scott and with the Earl of Selkirk. Macculloch's interest in geology was already obvious during his undergraduate years but grew as a result of his travels, and in 1801 he was elected fellow of the Linnean Society. His first professional appointment was as assistant surgeon to the Royal Regiment of Artillery, but in 1803 he applied for and was given the post of chemist to the Board of Ordnance. In 1807, he came to London, set up practice in Blackheath and was admitted, a year later, as licentiate of the Royal College of Physicians; he also became a member of the newly formed Geological Society of London. In 1811, dissatisfied with the practice of medicine, he returned to his studies in geology and was commissioned by the Board of Ordnance to go to Scotland, to determine the types of rocks most appropriate for use in powder mills. During the next few years, Macculloch continued with the study of Scottish rocks and accumulated a vast store of knowledge and experience. It was then that he conceived the idea of preparing a geological map of Scotland. In 1814 he was appointed geologist to the Trigonometrical Survey which was then preparing a one-inch topographical map of Scotland. During the summers of the next five years Macculloch toured many areas of the country collecting survey data. In the winters he lectured on chemistry and mineralogy at the Royal Military Academy in Woolwich. From 1816 to 1818 he was President of the Geological Society of London.

The year 1819 saw the publication of Macculloch's first major work, $A$ description of the Western Isles of Scotland including the Isle of Man. A year later his appointment to the Board of Ordnance was terminated because the Master General of the Ordnance, the Duke of Wellington, refused to sanction any future expenditure for this post. ${ }^{10}$ In 1820 Macculloch was appointed physician-in-ordinary to Prince Leopold of Saxe-Coburg, and was elected F.R.S.; he was allowed to keep his original appointment as chemist to the Board of Ordnance until 1826. He was then informed that he might transfer his services to the Geological Survey under the Treasury and his application for completion of the geological map of Scotland was successful. Macculloch proceeded to Scotland immediately, and completed the field work in six years. ${ }^{11}$

In spite of his involvement in this major scientific enterprise, Macculloch found time to publish, during the period 1820-1832: two books on geology; a new four-

in a private feud with the Maxwells. They then settled at Cardoness on the river Fleet in Kirkcudbright. One of the ancestors was David MacCulloch, Lord Lieutenant of Galloway. (Annual Biography, op. cit., note 6 above, 1836, p. 25.)

-W. Munk, The roll of the Royal College of Physicians of London, London, Royal College of Physicians, 1878, vol. 3, p. 66.

${ }_{10}$ Eyles, op. cit., note 7 above.

11 Ibid. 


\section{J. Bruce-Chwatt}

volume edition, preceded by six letters to Sir Walter Scott, of his travels in the Scottish highlands; two treatises on malaria; three editions of his early study on the art of wine-making; and some sixty papers on other subjects. For several years he held the post of lecturer at the Honourable East India Company's military establishment at Addiscombe.

In the summer of 1835 , to the surprise of all his friends, since he was a solitary and introspective man, ${ }^{12} \mathrm{John}$ Macculloch married a Miss White, whose family resided near Addiscombe. A few weeks later, when travelling with her in Cornwall, he was thrown from their carriage and sustained a compound fracture of his right leg. An amputation proved to be necessary but a few days later John Macculloch died at the home of his friend Captain Giddy, R.N., in Poltair near Penzance, at the age of sixty-two. He was buried in Gulval, Cornwall.

Macculloch's breadth of interests and industry were remarkable. ${ }^{13} \mathrm{He}$ had a sound knowledge of geology, mineralogy, chemistry, mathematics, botany, and zoology, and was an able physician; he was something of a philosopher, an architect, an artist and a musician. In addition to his nine major books, he published seventy-nine scientific papers, mainly on geology but also on the art of making wine, on marine fishes and crabs, on Greek fire and on indelible ink. One of his papers is a description of twenty-two species of jelly-fish found on the coasts of Shetland and Orkney. As a writer his style tends to be verbose and rambling, though often enlivened by a brilliant remark or spiced by touches of caustic wit.

Macculloch as moralist was severely taken to task by his fellow Scots for criticizing in his Description of the Western Isles, $(1819$, vol. 2, p. 47), the apparent indolence of the coastal Celts, for expressing doubts about their "military propensities" and for being less than enthusiastic over Highland music.

The harshest review of Macculloch's book came from James Browne, whose book A critical examination of Dr. Macculloch's work on the Highlands contained virulent personal attacks on the author. ${ }^{14}$ Incidentally, Browne's volume of 160

12 Macculloch's character was praised by his friends. "He was steady in his attachments, zealous to promote the interests of his friends, and ever ready to aid those who needed his assistance. He possessed very strong affections and acute sensibility which the sufferings of many years seemed rather to have increased than diminished. His manners were courteous; his conversation was rich, varied, apparently exhaustless, though never urged so far as to exclude others, and remarkable for its unaffected simplicity." Annual Biography, op. cit., note 6 above, p. 33.)

13 An anonymous obituary describes Macculloch's talents and achievements as follows: "The more we reflect on what he did, the more we admire the variety and extent of his knowledge and the wisdom and benevolence with which he applied it to promote the welfare of others. . . . His skill in drawing was exquisite and the number he has left is very great, independent of those which he gave away. His flowers were examined, dried and painted, before breakfast in the long summer mornings. When he used to play the violin, he practised it always during the twilight hours, when he could have seen neither to read or to write." (Annual Biography, op. cit., note 6 above, p. 32.)

${ }^{14}$ "We do without qualification aver, that on everything regarding the actual manners, character and condition of the Highlanders the Doctor is a prejudiced person in the worst sense of the term; one of the principal objects he had in view in manufacturing this book, and secondary only to his love of displaying his own prodigious erudition, was to white wash the Highland landlords and to justify the proceeding to which they have had recourse, by representing the native population on their estates as brutalized beyond all hope of regeneration; and that therefore, all his statements connected with this subject are those received with extreme suspicion and distrust." (J. Browne, A critical examination of Dr. Macculloch's work on the Highlands and western islands of Scotland, Edinburgh, D. Lizars, 1825, p. 27.) 
pages is preceded by a motto from Burns: "Some books are lies, frae end to end". Macculloch anticipated this response, but was surprised by its violence. In the preface to his book (p. x) he writes, "If the warmth of Caledonian feelings on the subject which relate to Scotland has anywhere been offended, it would be a source of regret. The writer has himself carried into that country no small share of Caledonian affections, hereditary and acquired; but he has attempted to view these questions with the eye of an unprejudiced "Sassanach"(!)"15

As a scientist Macculloch was well known and admired, though not without some restrictions. Sir Charles Lyell in an obituary notice to the Geological Society paid him a not unmixed tribute. ${ }^{16}$

An assessment of Macculloch's work as geologist was made in 1937 by Eyles ${ }^{17}$ who stressed that his geological survey of Scotland and the relevant map deserve more recognition than they have received. The survey is remarkable not only because

\footnotetext{
"But the truth is that the fanfaronade about Highland indolence and laziness is all miserable cant, put forward as an excuse for proceedings totally indefensible and which, as we shall show in another part of this critique, have been found as unprofitable, in an economic point of view, as they are incompatible with patriotism or humanity." (Ibid., p. 165.).
}

Browne had serious doubts about the statement that Macculloch's book was based on letters to Sir Walter Scott and accused the author of ". . . an unpardonable breach of decorum, of which, however, we could easily have believed Macculloch guilty; he had either employed Sir Walter's name without his consent or abused his confidence by concealing from him the pollution contained in his book. ..." (Ibid., p. 173.)

${ }_{13}$ In Macculloch's brief obituary published in the Gentleman's Magazine $(1835$, p. 556) there appears the following sentence: “. . . author of a Description of the Highlands and western isles of Scotland, which gave great offence to that nation."

16 "... At the same time that measures are thus in train for completing a Geological Map of England on a magnificent scale, the Map of Scotland, by Dr. MacCulloch, which has been so long and impatiently expected, is at length on the eve of publication. But at the moment when I can announce this welcome intelligence we have to deplore the sudden loss of this distinguished philosopher. The first paper in the first volume of our Transactions was from the pen of Dr. MacCulloch, and subsequent volumes contain no less than eighteen of his memoirs. It would lead me far beyond my present limits were I to attempt to give a general analysis of these and of his numerous other works on geology, such as his Western Islands and his Classification of Rocks. The influence exerted by them on the progress of our science has been powerful and lasting, yet they have been less generally admired and studied than they deserve. Their popularity has been impaired by a want of condensation and clearness in the style, a defect which no one could more easily have remedied than the author, had he been willing to submit to the necessary labour. Another blemish has also contributed to give a repulsive character to some of his later productions, especially in his System of Geology, the absence or apparent absence, of all enthusiasm and love for his subject, and a disposition to neglect or speak slightingly of the labours of others, and even to treat in a tone bordering on ridicule some entire departments of science connected with geology, such as the study of fossil conchology. I attribute these imperfections principally to habitual ill health acting upon a sensitive mind, for certainly Dr. MacCulloch's spirits were much depressed by bodily sufferings when I had first the pleasure of knowing him, about the year 1825 . His imagination was then haunted with the idea that his services in the cause of geology were undervalued, and it was in vain to combat this erroneous impression. After that period he almost entirely withdrew himself, even when residing in London, from all personal intercourse with the most active geologists; and to those who knew him this seclusion from scientific society was a subject of frequent regret. Having expressed myself thus unreservedly on some of the peculiarities and defects of his style. I may affirm that as an original observer Dr. MacCulloch yields to no other geologist of our times, and he is perhaps unrivalled in the wide range of subjects on which he displayed great talent and profound knowledge. For myself I may acknowledge with gratitude that $I$ have received more instructions from his labours in geology than from those of any living writer." (Lyell, op. cit., note 6 above.)

${ }^{17}$ Eyles, op. cit., note 7 above. 


\section{J. Bruce-Chwatt}

it was the first official geological survey of any country in the world but also because it was done by a single individual and ranks together with Wm. Smith's pioneer geological survey of England and Wales. It involved an immense amount of travelling, much of it through wild, mountainous country without roads or accurate topographical maps. ${ }^{18}$

The map, finished in 1832 and eventually published in 1836 by S. Arrowsmith, is the first detailed geological map of Scotland, valuable even today.

Macculloch's appreciation of geology not only as an exact science but also as an essential part of the landscape and source of natural beauty was recently stressed by Secord, who said: "MacCulloch's best work ... contains scenes like the paintings of Turner and Martin, filled with constantly changing effects of light and atmosphere. These intensely emotional experiences, like the view of Staffa, which inspired MacCulloch's classic 'Description of the Western Islands' produced more than brief bursts of lyrical writing in otherwise scientific works." $18 \mathrm{a}$

In spite of Macculloch's devotion to geology he did not neglect his professional medical training. His prodigious memory, powers of observation and his talent as a naturalist led Macculloch to the study of the disease that has been associated for centuries with marshes and swamps. His two books on malaria deserve to be better known and remembered as an important British contribution to the history of tropical medicine. ${ }^{19}$

The first, published in 1827, is entitled, Malaria, an essay on the production and propagation of this poison, and on the nature and localities of the places by which it is produced etc. In the introductory remarks, which form the first chapter of this work, Macculloch writes: "It has long been familiar to physicians that there was produced by wet lands, or by marshes and swamps, a poisonous and aeriform substance, the cause not only of ordinary fevers, but of intermittents; and to this unknown agent of disease the term marsh miasma has been applied ..." (p. 1). And then: "This is the unseen, and still unknown, poison to which Italy applies the term, that $I$ have borrowed, Malaria ..." (p. 2).

The book starts with a discourse ". . . on the effects of Malaria and on the utility of a knowledge on that subject"; it then describes the ". . . nature of the evidence respecting the production of Malaria in situations of a less notorious or acknowledged character. ..." The following two chapters deal with ". . . the soils and situations which most commonly produce Malaria ..." or "are less conspicuously productive of Malaria or as yet unsuspected of it. ..."Here Macculloch stresses that intermittent fevers were and are much more common [in the eighteenth and early nineteenth centuries] in England and in France than previously suspected.

Other chapters give an account of "certain obscure or disputed cases relating to the production of Malaria ..." "... whether from natural causes or from artificial

\footnotetext{
18 Ibid., p. 115.

18a J. A. Secord, 'John Macculloch; Geology and the appreciation of landscape'. (Paper read at the summer meeting of the British Society for the History of Science, University of Southampton, 8 July 1976 ; in press.)

10 "Macculloch made malaria and its consequences his special medical study and in his two treatises brought together such an amount of curious and instructive information as has rarely been collected on any medical subject." (Munk, op. cit., note 9 above.)
} 
sanitary measures ..." and discuss "... the climates and seasons peculiarly favourable to the production and propagation of the effects of Malaria. ..." A chapter on "the Geography of Malaria" gives a remarkably accurate description of the importance and distribution of the disease in France, Italy, Greece, Spain, Flanders, North America and the West Indies. The last two chapters describe the "nature of Malaria" and "the general effects of Malaria upon the constitution of the inhabitants of marshy districts, and on the diseases which seem to be produced by it. . . ."

It should be made clear that the term "malaria" as introduced by Macculloch referred to the hypothetical cause of the infection and not to the disease itself. The paludal origin of intermittent fevers, mentioned already by Columella in the first century A.D. was stressed in the eighteenth century by Giovanni Maria Lancisi and was generally accepted. ${ }^{20}$ However, Lancisi's tentative suggestion that there is a link between the abundance of mosquitoes in swampy places and some "contagium vivum" that produces the disease, gained no ground. The crude theory that a poisonous substance emanating from marshes is the culprit, remained the only explanation up to the end of the nineteenth century. But in the discussion of the origin and consequences of the disease Macculloch ranges over a wide field. He points out that while swamps are often malarious, some marshes are harmless, and that the fever may be present near flowing waters; he stresses the benefits of drainage and afforestation, warns of the adverse effects of malaria in military campaigns or sea-borne trade with tropical countries, criticizes the physicians for not recognizing and acquainting themselves with the disease, emphasizes the effects of endemic malaria on the indigenous populations, suggests some elementary measures of protection and pleads for better study of the subject. Much of it is logical and sound in the light of present knowledge of the transmission of malaria.

Macculloch shows an intuitive understanding of the natural history of a disease and an excellent appreciation of the role of the environment in the propagation of malaria. Some statements are surprising in their early recognition of socio-economic effects of this disease in highly endemic areas; e.g. "... Let me urge what I said before, that Malaria produces, in itself, a far wider mass of human misery than any other cause of disease...." (pp. 31-32).

His second book on the subject of malaria: An essay on the remittent and intermittent diseases including marsh fever and neuralgia etc. (1828) is in two volumes. In the first Macculloch discusses "... the ordinary Remittent or Marsh Fever" and states "There scarcely appears a reasonable ground of doubt in the present day, that the cause of remittent fever in its perfect form is the application of Malaria ...." (p. 4). He remarks that persons who reside in hot climates acquire a power of resistance or a "seasoning" and describes the symptoms of the acute disease including the comatose states.

In describing "the chronic or relapsing and obscure or anomalous remittents" Macculloch draws attention to the varied symptomatology of a number of febrile diseases and obviously confuses malaria with other infections.

On the cure of remittent fever, the author believes that the value of the Cinchona

${ }^{20}$ Giovanni Maria Lancisi, De noxiis paludum effluviis eorumque remediis, Libri duo, Rome, Jo. Mariae Salivioni, 1742. 


\section{J. Bruce-Chwatt}

bark depends on the condition of the patient, stresses the divided opinion of many contemporary authors but adds that ". . . the utility of bark or of tonics in general is scarcely disputed in those cases where the symptoms are those of debility ..." (p. 162). He condemns the common practice of bloodletting and is violently opposed to the then usual practice of treating almost every febrile disease with calomel. ${ }^{21}$

The chapter on intermittent fevers is remarkable for its vivid description of the cold, hot and sweating stage of the malaria paroxysm and the relapsing forms of it but writing about "obscure intermittents" there are few affections that are not ascribed to malaria.

In the discussion of cure of intermittents the author ridicules the use of charms and such nostrums as cobwebs. He stresses the value of the Peruvian bark given in proper dosage, doubts the efficacity of arsenic, castigates (once again) the abuse of calomel and that of purging and fasting. Most of the first volume of Macculloch's second book is a good review of the state of medical art of that period and much of the text is consistent and sound by the standards of his time.

In the second volume of his 1828 work Macculloch takes up one particular theme, which he mentioned briefly in the first book, namely the causal connexion not only between the "malarial poison" and febrile conditions but also with regard to a large number of other symptoms, presented together under a generic name of neuralgia. Here, the author's fertile imagination and facility for formulating hypotheses become extravagant. His insistence on considering malaria as the main cause of neuralgia is odd.

In attempting to prove his point Macculloch even introduces a symbolic mathematical equation ${ }^{22}$ to explain the action of various factors on the appearance of neuralgia, probably one of the early uses of biomathematics in a medical text, to support a hypothesis.

In a tabular presentation of the effects of marsh fever Macculloch connects the disease with numerous nervous and other disorders such as epilepsy, catalepsy, hysteria, spasmodic cough, fatuity, hypochondriasis, headaches, dyspepsia, chlorosis, menorrhagia, diabetes, rheumatism, sciatica, phthisis, dysentery, cholera. He states that some "endemies" are said to be produced by malaria and includes in the list scurvy, pellagra, rickets, cretinism, hernia, elephantiasis, and scrofula, among other affections.

${ }^{21}$ Because of the pernicious influence of James Johnson working in Calcutta, Cinchona in malaria treatment was superseded in the early 1820 s by mercury, which did much damage to the unfortunate patients. (G. M. Findlay, Recent advances in chemotherapy, 3rd ed., London, J. \& A. Churchill, 1951 , vol. 2, p. 284.) Macculloch's indignation was justifiable and one can only admire the force with which he stated his view, as follows: ". . . besides the unconscious dead, there are thousands living to rue the day when mercury became the universal Medicine in the hands of English physicians, ... Well may entire Europe wonder at English practice; and more still may it express its surprise at that universal self-empiricism, before which all the professed quackery of all Europe shrinks into nothing and in comparison of which the temporizing ptisanerie of France is absolute philosophy ...." (Macculloch, 1828, p. 211.)

28 "This is not a piece of algebraic affectation; since it is impossible to reason without a symbol of some kind, and we cannot apply terms expressive of ideas, before we are possessed of the ideas themselves. When the value of $x, y$ and $z$ and of $w$ also, though a remoter condition, or more properly an effect than a cause, shall hereafter be discovered by physiologists, it will be easy to give a better form to these remarks and to do much more as to the whole of this subject than I can at present even conjecture." (Ibid., p. 443.) 
All this seems strange and baffling when stated by a person with Macculloch's critical intellect and considerable scientific achievements, especially as these views are not supported by any factual evidence such as improvement after appropriate treatment. ${ }^{23}$ It is perhaps regrettable that this diffuse and rambling treatise alters the favourable impression left by his first book on malaria.

It would be impossible to quote or discuss the many observations, right or wrong hypotheses, caustic and witty comments, lengthy philosophical digressions, which abound in Macculloch's first book on malaria (1827) and characterize the personality of this remarkable man. A few extracts will give an idea of his thoughts and his style. ${ }^{24-30}$

${ }^{23}$ In the matter of treatment of "marsh fevers" by Cinchona bark or by the (then recent) use of quinine sulphate, Macculloch agrees with the general opinion that this is the most efficacious drug, but he also stresses that its effect is disappointing in dealing with the symptoms classified as various forms of neuralgia. Thus the blame is laid on the shortcomings of the remedy rather than on the want of a diagnostic acumen! Oddly enough, the possibility of prophylactic use of Cinchona was not considered by Macculloch, although according to Findlay already in 1777 James Lind stated that since the last edition of his Essay on the diseases incidental to Europeans in hot climates of 1771 "the ships of war on the Guinea station are ordered to be supplied with a large quantity of bark in powder and of wine to be issued occasionally to those who are sent in boats up rivers and on shore. ..." Moreover, in 1826 the preventive value of Cinchona bark against tropical fevers was demonstrated on the crew of H.M.S. North Star in Sierra Leone and reported by Boyle in 1831 (Findlay, op. cit., note 21 above, vol. 2, pp. 283-285).

24 "... we do know, from ample experience, that Malaria occurs in abundance when there is no smell and no putrescence, and that the process of vegetable putrefaction, in the ordinary sense of that term, is not necessary to its production. There is good reason therefore why we should shun the vicinity of putrescent and vegetating waters, but there is infinite hazard in rendering this doctrine and this error exclusive. ..." (Macculloch, 1827, p. 102.)

25 "... With a view to this fact, this series of gradually diminishing evil, of successive improvements in the condition of land in our own country, and also elsewhere, attended by a diminution of diseases equally progressive and proportional, and therefore proving a gradual diminution of the generation of Malaria, it would be neither unamusing nor uninstructive to trace the corresponding progress of health and drainage; ... while the success of that which has been done ..., holds out encouragement to such further attempts as yet are wanting: the neglect of which is not justified by the conviction that little remains comparatively to be effected, since in the present state of our society, a small quantity of endemic disease is, for many obvious reasons, as great an evil as a much larger one was when human life was of less comparative value, ... while it is not questioned that the protection of the public health, is not less the duty of an economist and a politician, than it is a duty of mere humanity. ...." (Ibid., pp. 125-126.)

26 ". . . In reality, I entertain no doubt, that while we must suppose contagious fever to occur occasionally in ships, from various obvious causes, the great and frequent mortality in them has ever proceeded from this very cause, Malaria ... produced by the neglect of cleanliness; ... I entertain no doubt, that if this rule [of cleanliness] were made imperative on all commanders of vessels, not only in the Navy, . . . but in the merchant service, by ship owners, and very especially by the West Indian trade, the fevers which are now so frequent would disappear. . .." (Ibid., p. 148.)

27 ". . . But, as to public matters, it is chiefly in military service that the ravages made by the diseases of Malaria have been frequent, serious, and often ruinous; while if those have sometimes been inevitable, they have much too often been the results of neglect or . . . ignorance. . .." (Ibid., p. 225.)

${ }^{28}$ When it comes to prevention from malaria, Macculloch advises ". . . not to leave the house in the morning without food, or without the previous use of spirituous liquors; and hence also the great use of tobacco in Holland, as well as its adoption by military men in campaigns. . . ." (Ibid, p. 288.)

And then: "... I shall . . . proceed to examine that problematical fact ... relating to the personal prevention of disease under the presence of Malaria. The fact, as it is stated is simply this: that by 


\section{J. Bruce-Chwatt}

Both books were reviewed anonymously in the Quarterly Journal of Science, Literature and Art in 1827 and 1828. The review of the first book was condescending and treated the whole essay as a lightweight exercise, showing more imagination of the author than his true knowledge. On the other hand, (mirabile dictu), the lengthy review of the second book praised its author, for having "conferred a most essential benefit on mankind, as well as on his own profession, by investigating, describing and classifying, under certain general and leading principles, what was an entire mass of neglect and obscurity as far as theory is concerned, as in practice it was a chaos of empiricism and error; nor do we hesitate in saying that it is the most important contribution which has yet been made to medical science."31

Today, some 150 years after the publication of Macculloch's book, which introduced the term "malaria" into English scientific writing, we live at the time when the attempted global eradication of malaria is still far from its goal. The last few sentences of John Macculloch have a poignant ring. But they also imply that the unfinished task of curbing what Ronald Ross called the "million murdering death" must continue with all the means at our disposal.

The following is a list of John Macculloch's works referred to above. Fuller references to Macculloch's published works will be found in the British Museum's Catalogue of printed books, 1962, vol. 148, pp. 176-177.

surrounding the head with a gauze viel [sic] or conopeum the action of Malaria is prevented. . . " (Ibid., p. 289.)

${ }^{29}$ In describing malaria in Greece, Macculloch, writing barely two years after the death of Byron, has this to say: ". . . With the name of Missolonghi just dropping from my pen, I cannot well avoid making a remark on the fate of our great poet: a remark which refers to ... the ignorance, or error, respecting the fevers of Malaria which is so prevalent, and the consequent maltreatment to which they are often subject. And in using these terms I do not merely allude to that error so nearly universal among ourselves at home, which does not perceive the situations productive of Malaria; ... such errors being productive of corresponding erroneous treatment or neglect, often attended by fatal consequences. . . . Had an English, untravelled, practitioner, committed this, not merely error, but series of errors, it would have excited no surprise, since that occurs in our own country every day; but that an Italian physician should not have perceived the disorder to be the remittent fever, though in a slight or obscure form, that he should have persisted in his mistakes to the last, converting a mild disease into a severe one ... . is nearly incredible. Whether Lord Byron would have died of that fever, under proper treatment, HE alone to whom the book of Fate lies open knows; but while many must feel that indignation, as well as regret . . . it is difficult at least not to think ... that the death of this lamented personage was caused by the ignorance of his physician; if ever that act was committed by physic. ..." (Ibid., pp. 388-390.)

${ }^{20}$ And finally: ". . . If the great proportion of the fevers which occur among mankind, in our own country as in others, are fevers from Malaria, if this is especially true of those which are serious or severe, omitting always the fevers from contagion, then are we in possession of the cause; and to possess that, is the first step towards prevention.... And all this depends, primarily, on our proving the real cause of such fevers, and secondarily on our proving the causes of that cause; this last knowledge principally, being that which the present researchers have attempted to investigate. . . I cannot help believing that even what is here done, will, in the end, prevent a great mass of evil, or of suffering and death .... and essentially, as I trust . . . diminish the total sum of human misery. ..." (Ibid., pp. 479-480.)

31 [Review of] Malaria: an essay on the production and propagation of this poison, by J. Macculloch, 1827; Quart. J. Sci., Lit. Art. London, The Royal Institution of Great Britain, July-October 1827, pp. 100-108. [Review of] An essay on the remittent and intermittent diseases, by J. Macculloch, 1828; ibid., January-June 1828, pp. 34-62. 


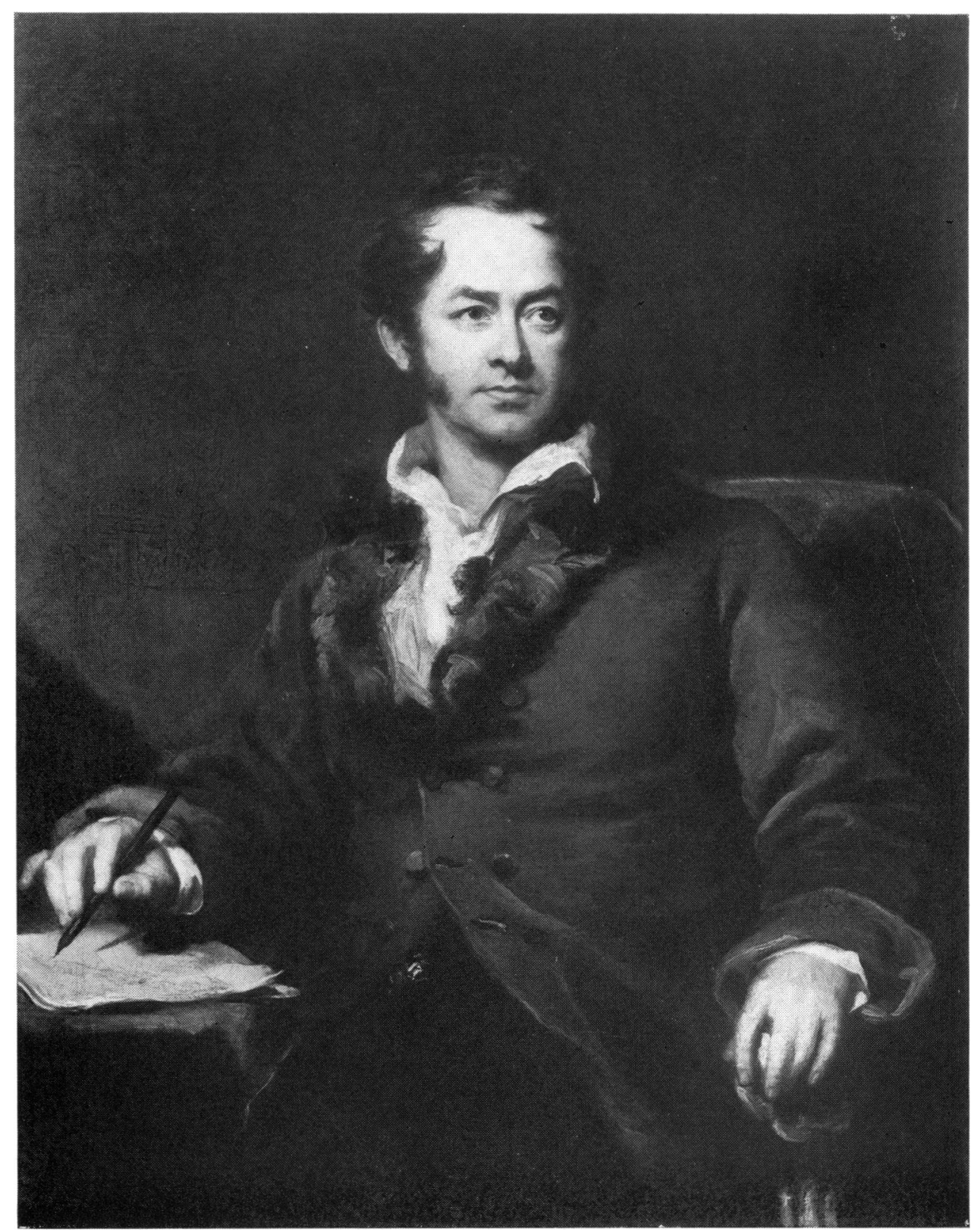

Figure 1.

John Macculloch, M.D., F.R.S. (1773-1835). This portrait of Macculloch, painted in oils for the Royal Society by B. A. Faulkner, was engraved in 1837 by C. E. Wagstaff and published by B. A. Faulkner, 23 Newman Street, London. A copy of this excellent engraving was made available through the courtesy of Mr. John Thackray of the Geological Department of the British Museum. (Reproduced by kind permission of the Royal Society of London.) 
A description of the western isles of Scotland, including the isle of Man, comprising an account of their geological structure: with remarks on their agriculture, scenery and, antiquities, 3 vols., London, printed for Constable, Edinburgh by Robinson, 1819.

A geological classification of rocks, with descriptive synopses of the species and varieties, comprising the elements of practical geology, London, Longman, 1821.

The Highlands and western isles of Scotland, containing descriptions of the scenery and antiquities: with an account of the political history and ancient manners, and of the origin, language, agriculture ... of the people. Founded on a series of annual journeys between 1811 and 1821. ... In six letters to Sir Walter Scott, Bart., 4 vols., 1824.

Malaria: an essay on the production and propagation of this poison, and on the nature and localities of the places by which it is produced; with an enumeration of the diseases caused by it, and of the means of preventing or diminishing them, both at home and in the naval and military service, London, Longman, Rees, Orme, Brown \& Green, 1827.

An essay on the remittent and intermittent diseases including, generically marsh fever and neuralgia; comprising under the former various anomalies, obscurities and consequences and under a new systematic view of the latter treating of tic douloureux, sciatica, headache, ophthalmia, toothache, palsy and many other modes and consequences of this generic disease, 2 vols., London, Longman, Rees, Orme, Brown \& Green, 1828; Philadelphia, Carey \& Lea, 1830.

\section{SUMMARY}

An account is given of the life and work of John Macculloch, M.D., F.R.S. (17731835), who introduced the term "malaria" into English scientific writing in his first published work on the subject in 1827. Macculloch was also an eminent geologist, and was responsible for the first geological survey of Scotland, completed in 1832. His published works reflect a wide range of interests, and his powers of observation and natural talents led him to his study of malaria, which represents an important contribution to the history of tropical medicine, generally and malariology in particular.

\section{ACKNOWLEDGEMENTS}

I am grateful to Mr. N. H. Robinson, Librarian of the Royal Society, for permission to publish the photograph of the portrait of John Macculloch and to Mr. E. J. Freeman, Librarian of the Wellcome Institute for the History of Medicine, for many facilities. 